\title{
BMJ Open Association between informal employment and mortality rate by welfare regime in Latin America and the Caribbean: an ecological study
}

\author{
Michael Silva-Peñaherrera (D) , ${ }^{1}$ María López-Ruiz, ${ }^{1}$ Pamela Merino-Salazar, ${ }^{2}$ \\ Antonio Ramon Gomez Garcia, ${ }^{3}$ Fernando G Benavides ${ }^{1}$
}

To cite: Silva-Peñaherrera $M$, López-Ruiz M, Merino-Salazar P, et al. Association between informal employment and mortality rate by welfare regime in Latin America and the Caribbean: an ecological study. BMJ Open 2021;11:e044920. doi:10.1136/ bmjopen-2020-044920

- Prepublication history and supplemental material for this paper is available online. To view these files, please visit the journal online (http://dx.doi. org/10.1136/bmjopen-2020044920).

Received 18 September 2020 Accepted 04 July 2021

Check for updates

(C) Author(s) (or their employer(s)) 2021. Re-use permitted under CC BY-NC. No commercial re-use. See rights and permissions. Published by BMJ.

${ }^{1}$ Center for Research in Occupational Health, Universitat Pompeu Fabra, IMIM (Hospital del Mar Medical Research Institute), Universitat Pompeu Fabra, Barcelona, Spain

${ }^{2}$ Facultad de Ciencias del Trabajo y Comportamiento Humano, Universidad Internacional SEK Ecuador, Quito, Ecuador

${ }^{3}$ Facultad de Post-Grados, Universidad de Especialidades Espiritu Santo, Samborondon, Ecuador

Correspondence to Dr Michael Silva-Peñaherrera; michael.silvap@gmail.com

\section{ABSTRACT}

Objective We aimed to estimate the association between informal employment and mortality in Latin America and the Caribbean (LAC) by comparing welfare state regimes. Design Ecological study using time-series crosssectional analysis of countries. Informality was estimated from household surveys by the Center for Distributive, Labor and Social Studies in collaboration with the World Bank, and the adult mortality rates for 2000-2016 were obtained from the WHO databases. Countries were grouped by welfare state regimes: state productivist, state protectionist and familialist. We calculated the compound annual growth rate for each country and performed linear regression between the informality and the adult mortality rates stratified by sex and welfare state regime.

Setting Seventeen countries from LAC with available data on informality and adult mortality rates for 2000-2016. Primary outcome measure The association between informality and mortality by welfare state regime. Results Between 2000 and 2016, mortality rates decreased an average $1.3 \%$ per year and informal employment rates $0.5 \%$ per year. We found a significant positive association between informality and mortality rates (women: $R^{2}=0.48$; men: $R^{2}=0.36$ ). The association was stronger among the state regime countries (women: $\mathrm{R}^{2}=0.58$; men: $\mathrm{R}^{2}=0.77$ ), with no significant association among the familialist countries.

Conclusion Informal employment negatively impacts population health, which is modified by welfare state regimes. Addressing informal employment could be an effective way to improve population health in LAC. However, linkage with public health and labour market agendas will be necessary.

\section{INTRODUCTION}

Paid work is the principal source of income for the majority of people and the main method of wealth distribution. ${ }^{1}$ In Latin America and the Caribbean (LAC), approximately 280 million people have paid work, $53.6 \%$ of which via informal arrangements in which work is not regulated and the workers are not protected by labour regulations and social security. This percentage ranges from
Strength and limitations of this study

- This paper shows, for the first time, the association between informal employment and the adult mortality rate in 17 countries of Latin America and the Caribbean.

- We used the latest data from household surveys as the best available data to measure informality and the WHO mortality database.

- To reduce the variation in each year and to obtain a robust result, this study used 17 years of data on both informal employment and adult mortality.

- We fit the best linear regression model by considering the relationship between mortality and informality in each country as independent observations.

- Welfare state typology is an ecological variable used as a proxy of the labour market and social protection features and with some grade of variation among countries inside each typology.

$24.5 \%$ in Uruguay to $80 \%$ in Honduras, Guatemala, Nicaragua and Bolivia. ${ }^{2}$ Women, young people, lower social classes and people with low levels of education are the most affected by this form of employment. ${ }^{3}$ Most people enter the informal economy not by choice, but as a consequence of a lack of opportunities in the formal economy. ${ }^{4}$ In the case of women, they may be pressured to work in informal employment because of their care responsibilities and family constraints, ${ }^{5}$ and informal employment is most likely the only option they have to participate in the labour market. Informal jobs are less productive than formal jobs and reduce the public tax revenues. ${ }^{6}$

Empirical evidence of the impact of the informal economy and informal jobs on health and health inequalities is scarce, especially in middle-income and low-income countries. ${ }^{7}$ Previous studies have found that informal employment is associated with poor mental and self-reported health. ${ }^{8}$ In 
addition, precarious employment is known to be associated with mental health disorders, health risk behaviour, poor quality of life and occupational injuries, ${ }^{3}$ which negatively affect the health of workers, families and communities. ${ }^{10}$

There is a continuum between precarious and informal employment in which in many cases informality is the worst form of precarious employment. Precariousness (temporary arrangements, lower earnings and lack or low degree of autonomy and control over the work $)^{11}$ is a key element in defining informality, but it is not the defining component of the informality based on the conceptualisation by the International Labour Organization (ILO). Workers in informal employment have no access to social benefits, such as sickness absence, permanent disability or retirement pension, which are also characteristics of precarious employment. Therefore, they could be forced to work for as long as they are able when sick or aged. The low income associated with this form of work could put the individuals in a situation of poverty, economic vulnerability or financial insecurity and expose them to higher occupational risks than formal jobs. ${ }^{10}$

In 1999, the ILO promulgated the ILO Decent Work Agenda based on four pillars: promoting productive and freely chosen employment, guaranteeing rights at work, extending social protection and creating social dialogue. ${ }^{12}$ This strategy was updated with Objective 8 of the 2030 Agenda for Sustainable Development. ${ }^{13}$ Decent work and economic growth are key elements in improving both occupational and public health. ${ }^{14}$

In general, decent work is both a cause and a consequence of welfare state policies. The welfare state policies set parameters for social protection benefits, such as retirement and disability pensions, or subsidised unemployment. ${ }^{1}$ In this regard, regimes with universalism and comprehensive social provision of welfare (ie, protectionist countries) can better regulate employment arrangements and reduce the negative impact of working conditions on population health. ${ }^{8}{ }^{15}$ This is particularly important during periods of economic crisis, when sources of income via paid work tend to decline and working conditions deteriorate.

The welfare state was examined in LAC in 2008 by analysing labour commodification (the labour market's ability to provide decent employment), welfare decommodification (the ability to guarantee the population's well-being through redistributive policies, without labour market involvement), welfare familiarisation (the volume of unpaid care work within families) and regime performance (the effectiveness of public expenditure and resource allocation). ${ }^{16}$ This analysis classified the Latin American countries into three regimes: state productivist, state protectionist and familialist. In the state productivist regimes (Argentina and Chile), welfare decommodification relies on individual income. In the state protectionist regimes (Brazil, Costa Rica, Mexico, Panama and Uruguay), the state presence is strongest, and there are higher levels of welfare decommodification. Both of these state regime groups have high levels of labour commodification. In contrast, in the familialist regimes (Colombia, Ecuador, El Salvador, Guatemala, Peru, Dominican Republic, Venezuela, Bolivia, Honduras, Nicaragua and Paraguay), the welfare is mainly provided by community and family arrangements. In this type of regime, social policies are weak, and informal employment is the biggest share of the labour market. ${ }^{8}$

The adult mortality rate has decreased worldwide and could be the result of social and healthcare improvements. However, it has not decreased at the same rate in all socioeconomic groups, countries and regions, which have broad differences in mortality. ${ }^{17}$ The objective of the present study was to estimate the association between informal employment and general mortality in the adult population of LAC according to the type of welfare state regime.

\section{METHODS}

\section{Data sources}

This geographical ecological study used a time-series crosssectional analysis based on data collected by the Center for Distributive, Labor and Social Studies (CEDLAS) in collaboration with the World Bank database ${ }^{18}$ via household surveys between 2000 and 2016 in 17 countries in LAC: Argentina, Bolivia, Brazil, Chile, Colombia, Costa Rica, Dominican Republic, Ecuador, El Salvador, Guatemala, Honduras, Mexico, Panama, Paraguay, Peru, Uruguay and Venezuela. Informal employment was defined as salaried work in a small firm, non-professional self-employed or zero-income workers according to the ILO definition. ${ }^{19}$

The informality rate was estimated by dividing informal employment by the total employment in the country per 100 . Mortality data were extracted from the WHO database, ${ }^{20}$ which annually registers death by cause, age and sex as reported by the civil registration systems of the member states. We used adult mortality according to the WHO criteria and death between 15 and 60 years of age. This is premature mortality. ${ }^{20}$

We used data from 2000 to 2016 for both variables. This period was selected because data were available for both variables in most of the countries. However, informality data were not available for all years in all countries (online supplemental tables 1 and 2).

\section{Statistical analysis}

To determine the percentage decrease in rates, we calculated a linear regression for the informality rate and adult mortality rate over time, separately for each of the 17 countries (online supplemental figures 1 and 2). With the beta results from the linear regression, we calculated the compound annual growth rate (CAGR) providing the yearly percentage decrease.

To estimate the association, we calculated an average informality rate and an average adult mortality rate for the period 2000-2016 for each country. Using the 
resulting averages from the 17 countries and the two variables (informality percentage and adult mortality rate), we performed a linear regression analysis stratified by sex. We calculated the $95 \%$ CIs for the resulting betas and determination coefficients $\left(\mathrm{R}^{2}\right)$. We also estimated ecological rate ratios for women and men. We used beta 0 as the estimated intercept and beta one as the slope. ${ }^{21}$

Finally, to evaluate the welfare state effect, we repeated the second analysis, stratifying data by sex and welfare state regime. We grouped the three main welfare regimes into two groups according to the following criteria. The countries characterised by a bigger state and larger formal labour force (ie, the state productivist and state protectionist regimes) were the first group, comprising Argentina, Brazil, Chile, Costa Rica, Mexico, Panama and Uruguay. The second group was characterised by a mainly informal labour market and lower income per capita (ie, the familialist regimes), comprising Colombia, Ecuador, El Salvador, Guatemala, Peru, Dominican Republic, Venezuela, Bolivia, Honduras, Nicaragua and Paraguay.

\section{Patient and public involvement \\ No patient involved.}

\section{RESULTS}

In all countries, informal employment was higher among women, and the adult mortality rate was higher in men. The lowest informal employment rate in women was found in Chile (39\%) and the highest in Bolivia and Guatemala $(\sim 71 \%)$. The highest mortality rate was in men in El Salvador (285 per 1000 population) and the lowest in women in Chile (64 per 1000 population). Both rates declined during the study period in almost all countries (table 1). On average, the region rates decreased, with a CAGR of approximately $-1.3 \%$ per year in adult mortality and $-0.5 \%$ per year in informal employment. Adult mortality from 2000 to 2016 decreased fastest in Guatemala (-4\% in men and $-4.5 \%$ in women per year), and informal employment decreased fastest in women from Chile and Brazil ( $-4.2 \%$ and $-5 \%$, respectively).

The linear regression between the informal employment and adult mortality rates (average during study period; figure 1) showed a strong positive association $\left(R^{2}=0.48\right.$ in women and $R^{2}=0.36$ in men). Slope coefficients were significant for both women $(\beta=1.76,95 \%$ CI 0.75 to 2.77$)$ and men $(\beta=3.12,95 \%$ CI 0.84 to 5.39$)$. The ecological rate ratio for women was 16.19 and for men 7.63. Moreover, mortality was clearly higher in countries with high informal employment.

Stratifying by welfare regime (figure 2), we found a stronger association between the state regimes $\left(\mathrm{R}^{2}=0.77\right.$ in men and $R^{2}=0.58$ in women) and a steeper slope for the regression ( $\beta=1.9,95 \%$ CI 0.05 to 3.92 for women, and $\beta=4.87,95 \%$ CI 1.81 to 7.93 for men). In contrast, in the familialist regimes, the association almost disappeared $\left(R^{2}=0.07\right.$ in men and $R^{2}=0.04$ in women $)$, and the slope coefficients were not significant $(\beta=0.58,95 \%$ CI
-1.70 to 2.86 for women, and $\beta=-2.6,95 \%$ CI -10.10 to 4.89 for men).

\section{DISCUSSION}

This study shows, for the first time, an association between informal employment and the adult mortality rate in both women and men in LAC. Overall, the mortality rate increases almost two points for each point of increased informality. Paradoxically, when the analysis was stratified by welfare state regime, the association was stronger and significant among the state regimes, where informality and mortality rates were lower. However, in the familialist regimes, although the informality and adult mortality rates were higher, we found no significant association between informality and mortality.

The global association between mortality and informality, independent of the welfare regime, may be explained by economic and social mechanisms, such as income insecurity, poverty, precarious working and living conditions, violence, lack of access to health services and absence of social protection benefits. All of these are present to varying extents among informal workers. ${ }^{22} 23$ However, unexpectedly, this association was only observable in countries with more developed welfare states, where informality rates are somewhat lower.

We have two hypotheses to explain these results. On the one hand, the weak role of the state in the familialist regimes could explain why the association disappears for those countries. In these countries with low gross national income per capita and low social, education and health expenditures, ${ }^{24}$ medical care and social welfare services are poor and do not cover basic needs for both formal and informal workers. Many formal workers cannot pay for private health services, and they most likely have the same health conditions as informal workers with no social protection. In this regard, having a formal job would not be a sufficient condition for having good health. ${ }^{14}$ In addition, in countries with fragile state regimes, the high informality rates deplete state revenue, and the social protections and healthcare are provided mainly by families and the community. This results in small differences in health between informal and formal workers. Recent evidence from the region shows that countries with a higher prevalence of poor health, such as familialist countries, have lower health inequalities. ${ }^{25}$

On the other hand, among the countries in which the welfare state is larger and participation in formal employment in the labour market is higher (ranging from $70 \%$ in Chile to 55\% in Brazil during 2000-2016), the association is strong. The economic and social development related to this group of countries could shape this relationship. Thus, the legal and social protection of formal employees clearly has a positive effect on workers' health. In this context, informal employees remain without social protection or healthcare service coverage and in the worst working conditions, including low wages. Thus, the gap between formal and informal employees expands, and an 


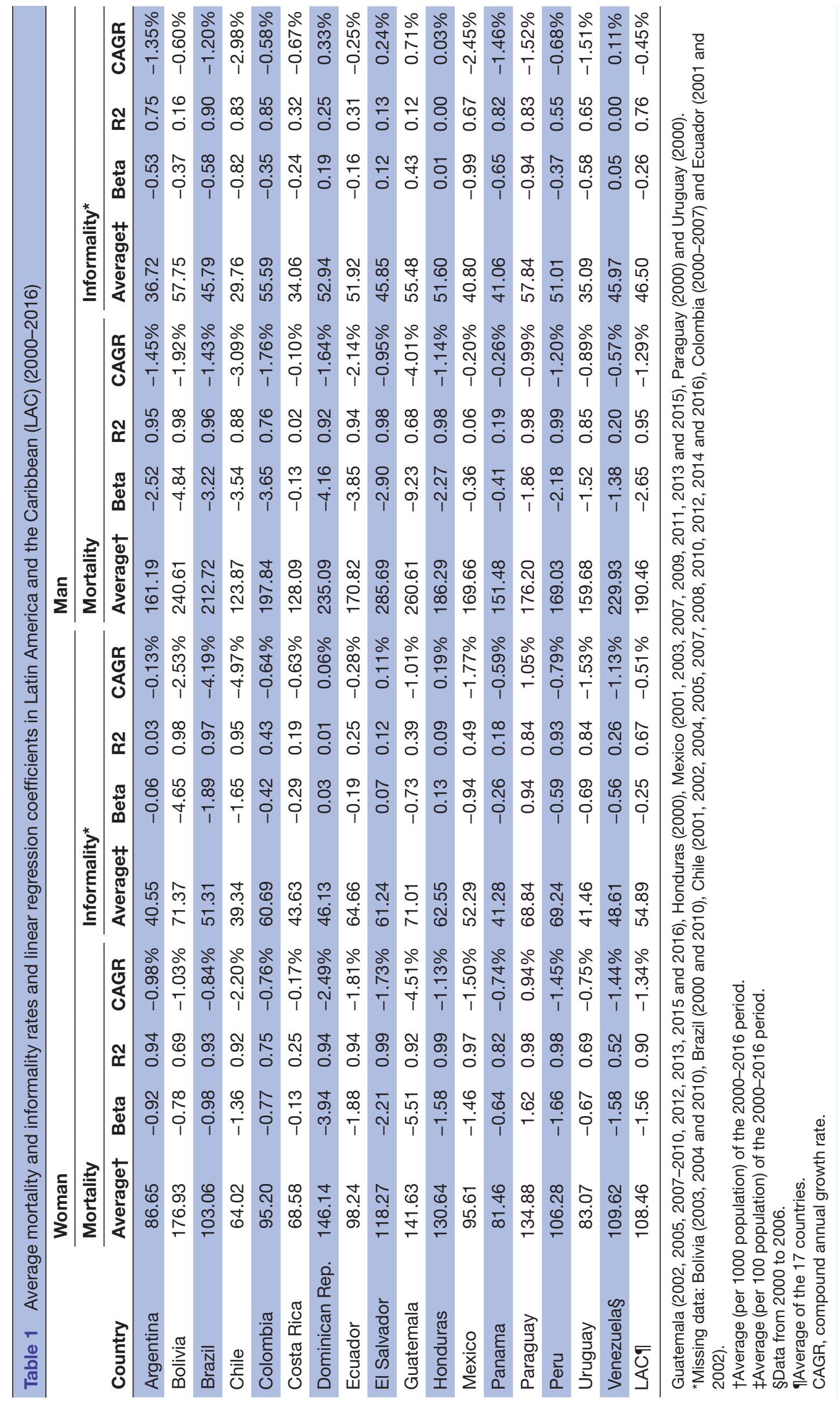




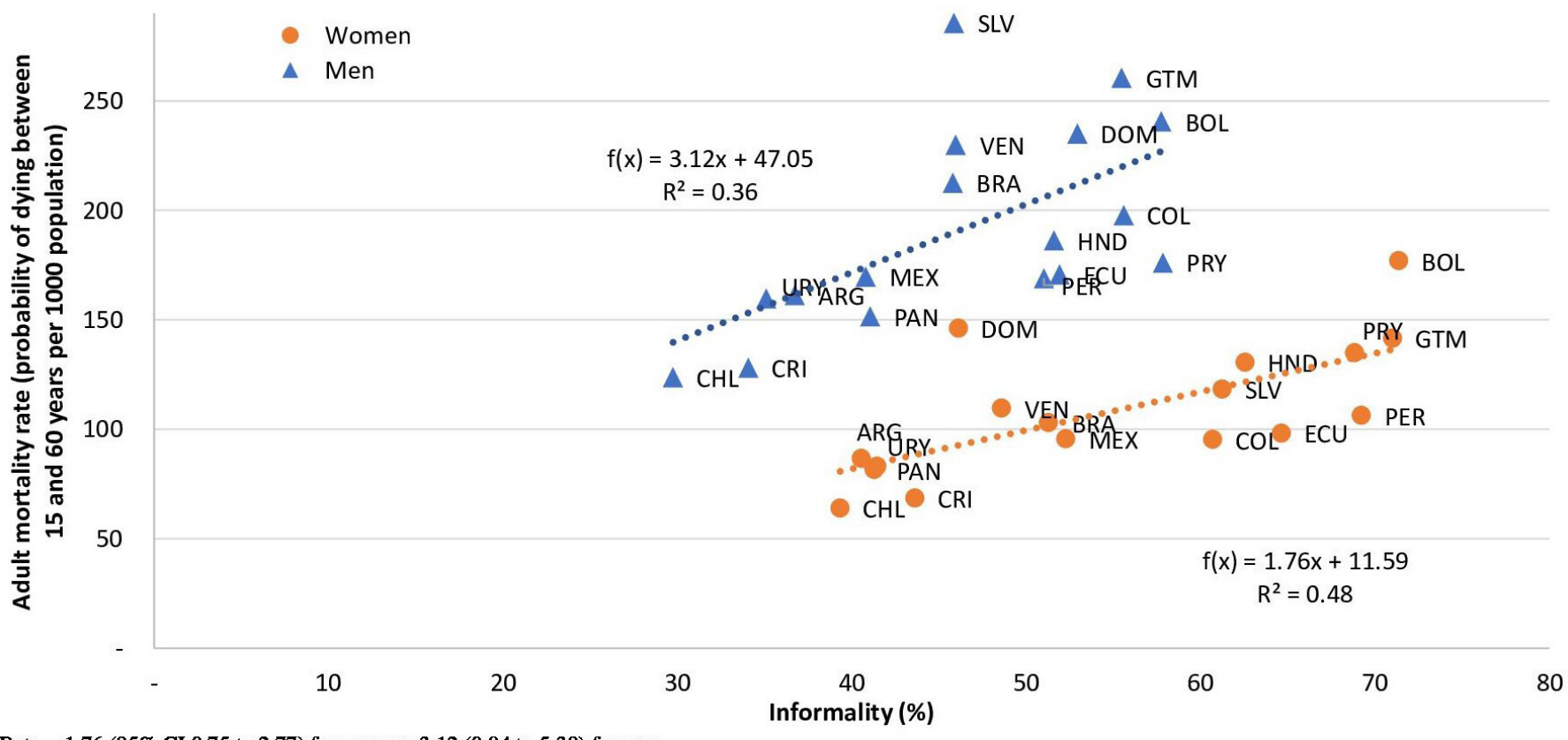

Beta $=1.76(95 \%$ CI 0.75 to 2.77$)$ for women; $3.12(0.84$ to 5.39$)$ for men

ISO-3 codes: ARG, Argentina; BOL, Bolivia BRA, Brazil; CHL, Chile; COL, Colombia; CRI, Costa Rica; DOM, Dominican Republic ECU, Ecuador, SLV, El Salvador, GTM, Guatemala; HND, Honduras; MEX, Mexico; NIC, Nicaragua; PAN, Panamá; PRY, Paraguay; PER, Peru; URY, Uruguay; VEN, Venezuela

Figure 1 Adult mortality and informality linear regression in Latin America and the Caribbean (2000-2016).

association with mortality is observed. Economic development without universal health services and generous social protection increases inequalities in health, leaving behind disadvantaged groups.

These results support the role of the welfare state as an important macro-level determinant of health. ${ }^{26}{ }^{27}$ This role is mediated by the labour market. Effectively, the taxes paid by workers and companies are the main source of financial support for social protection, health services and other welfare benefits to protect the health of the whole population. ${ }^{14}$ A similar effect was found in a study of Central American countries that demonstrated that a relationship

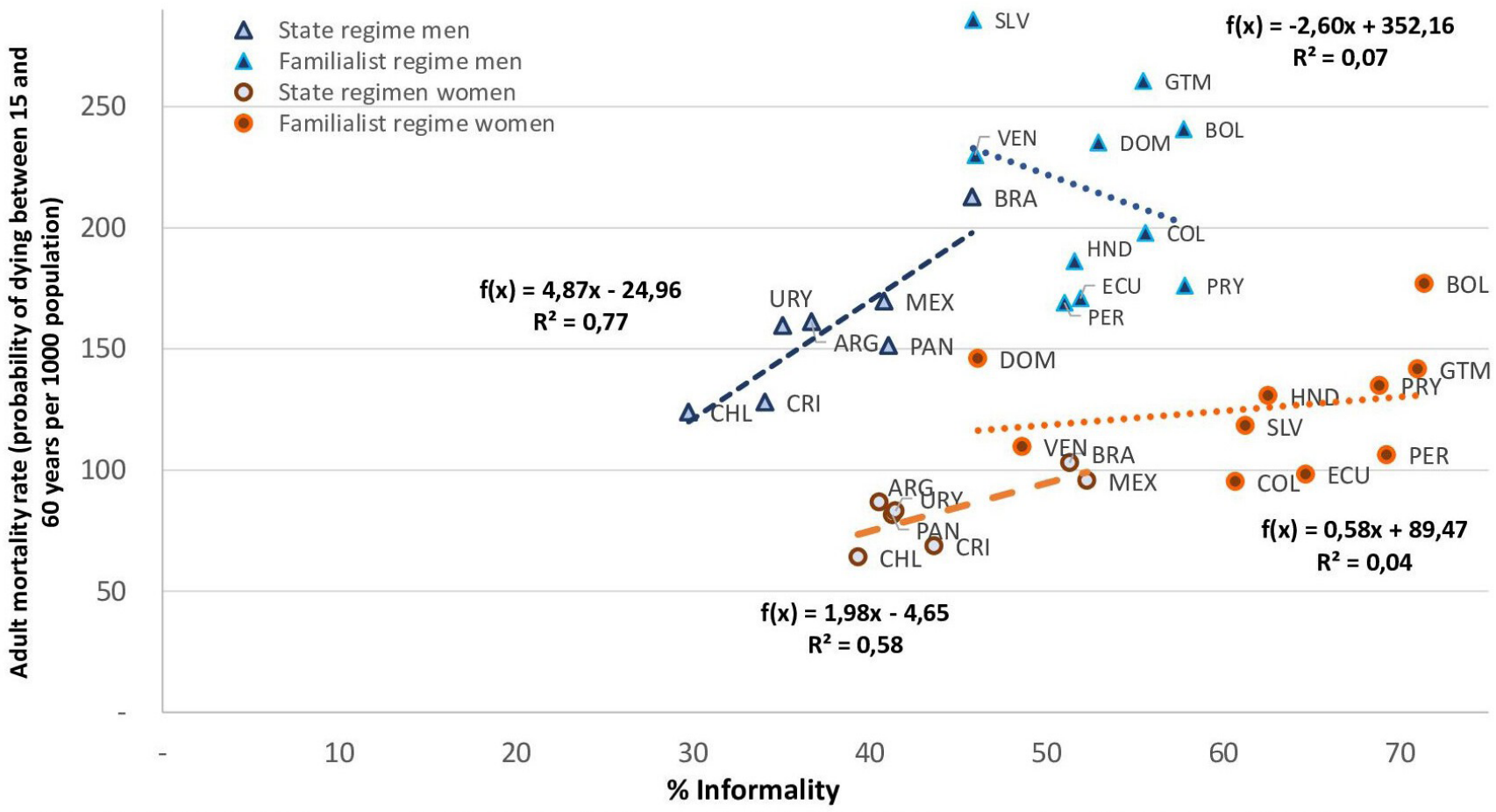

Beta $=1.98(95 \% \mathrm{CI} 0.05$ to 3.92$)$ for women-state; 4.87 (1.81 to 7.93) for men-state; 0.58 (-1.70 to 2.86) for women-familialist; $-2.6(-10.10$ to 4.89$)$ for men-familialist ISO-3 codes: ARG, Argentina; BOL, Bolivia BRA, Brazil; CHL, Chile; COL, Colombia; CRI, Costa Rica; DOM, Dominican Republic ECU, Ecuador, SLV, El Salvador, GTM, Guatemala; HND, Honduras; MEX, Mexico; NIC, Nicaragua; PAN, Panamá; PRY, Paraguay; PER, Peru; URY, Uruguay; VEN, Venezuela

Figure 2 Adult mortality and informality linear regression by welfare state in Latin America and the Caribbean (2000-2016). 
between self-perceived health and informal employment depended on the welfare regime. ${ }^{5}$ Along the same lines, a recent study carried out in Spain, a high-income country, did not find an association between self-perceived health and informal employment. The explanation was that universal healthcare and social services benefits cover both formal and informal employees. ${ }^{28}$

This study has limitations related mainly to the aggregated nature of our data. The informality rate was collected by the CEDLAS using microdata from national household surveys. However, household surveys are not uniform and could differ among countries, in both geographical coverage and the questionnaires. Household surveys also differ within countries over time and were not available for all of the countries in LAC over the 17 years. However, over the last decade, most of the governments in LAC have improved their surveys, standardising the coverage and questionnaires. ${ }^{18}$ In addition, the informality rate was calculated using similar definitions promoted by the ILO in each country, applying consistent methods for processing the data. Another limitation could be the under-reporting of deaths in some countries, since, according to the Pan American Health Organization (PAHO), it ranges from $53 \%$ to $99.8 \% .{ }^{29}$ However, we regress the average mortality and informality rates over 17 years. As it is shown in the supplementary materials, the rates were consistent over time, and we fit the best linear regression model by considering the relationship between mortality and informality in each country as an independent observation. The welfare regime typology used to stratify countries was examined 12 years ago. However, an update based on economic and social indicators of labour commodification and welfare decommodification revealed similar characteristics with the previous taxonomy, supporting the legitimacy of this welfare typology. ${ }^{24}$ Lastly, as in any other ecological study, our study could be affected by ecological bias; country-level data may poorly track relationships that exist at the individual level. In this regard, we cannot affirm that relationships observed for the groups necessarily hold for individuals. Finally, our analysis focused on all causes of deaths because specific causes of mortality were only available for 2 years. Future studies should analyse the relationship between informality and specific causes of mortality.

A strength of our study was that we used adult mortality, which is probably the most reliable health indicator available in the region and collected by the WHO for many years. The registry has proven to be reliable and consistent over time. ${ }^{30}$ Finally, we used 17 years of data on both informal employment and adult mortality to reduce the annual variation and to obtain a robust result.

In conclusion, although informal employment has decreased in the last few decades, it remains one of the most extended forms of employment in LAC. These high levels of informality greatly impact the adult mortality rate. High premature mortality has a high cost for the individual, family and society. Although the adult mortality rate has decreased in the region in the past two decades and also decreased worldwide, ${ }^{31}$ we would expect mortality rates to decrease most rapidly if informal employment is reduced more intensely. We should not forget that the welfare state will only be supported by persons with formal employment. Addressing informal employment in the region could be an effective way to improve the health of the working population and social vulnerability and prevent a significant number of premature deaths. Strategies linking public health and the labour market agenda will be necessary, and better information is needed to track changes in the labour market over time to plan, implement, monitor and evaluate the progress in terms of public health.

Contributors MS-P and FGB contributed to the conception and design of the study, data analyses and interpretation and drafting the manuscript. PM-S, ML-R and ARGG made substantial contributions to interpreting the results and reviewing the manuscript. All coauthors critically revised the manuscript for important intellectual content and gave final approval of the version to be published.

Funding This study was partially supported by the Center for Research in Occupational Health (CiSAL) Universitat Pompeu Fabra (UPF), Barcelona.

Competing interests None declared.

Patient consent for publication Not required.

Provenance and peer review Not commissioned; externally peer reviewed.

Data availability statement Data are available in a public, open-access repository. Data available in open-access websites http://www.cedlas.econo.unlp. edu.ar/wp/ and https://www.who.int/healthinfo/mortality_data/en/.

Supplemental material This content has been supplied by the author(s). It has not been vetted by BMJ Publishing Group Limited (BMJ) and may not have been peer-reviewed. Any opinions or recommendations discussed are solely those of the author(s) and are not endorsed by BMJ. BMJ disclaims all liability and responsibility arising from any reliance placed on the content. Where the content includes any translated material, BMJ does not warrant the accuracy and reliability of the translations (including but not limited to local regulations, clinical guidelines, terminology, drug names and drug dosages), and is not responsible for any error and/or omissions arising from translation and adaptation or otherwise.

Open access This is an open access article distributed in accordance with the Creative Commons Attribution Non Commercial (CC BY-NC 4.0) license, which permits others to distribute, remix, adapt, build upon this work non-commercially, and license their derivative works on different terms, provided the original work is properly cited, appropriate credit is given, any changes made indicated, and the use is non-commercial. See: http://creativecommons.org/licenses/by-nc/4.0/.

ORCID iD

Michael Silva-Peñaherrera http://orcid.org/0000-0001-5133-181X

\section{REFERENCES}

1 Bambra C. Work, Worklessness, and the political economy of health. Oxford: Oxford University Press, 2011.

2 International Labour Organization. Women and men in the informal economy: a statistical picture (third edition). Geneva: ILO, 2018.

3 Vancea M, Utzet M. How unemployment and precarious employment affect the health of young people: a scoping study on social determinants. Scand J Public Health 2017;45:73-84.

4 Bóo FL, Lucia M, Pagés C. Part-Time work, gender and job satisfaction: evidence from a developing country. J Dev Stud 2010;46:1543-71.

5 Lopez-Ruiz M, Benavides FG, Vives A, et al. Informal employment, unpaid care work, and health status in Spanish-speaking central American countries: a gender-based approach. Int $J$ Public Health 2017;62:209-18.

6 International Monetary fund. Labor market dynamics and informality over the business cycle in lac. in: regional economic outlook: Western hemisphere, 2019: 1-33. https://www.imf.org/en/Publications/ WP/Issues/2020/01/31/Labor-Market-Dynamics-Informality-andRegulations-in-Latin-America-48893IMF WORKING PAPERS 
7 (CSDH) $\mathrm{C}$ on SD of H, (EMCONET) ECKN. Employment conditions and health inequalities - final report to the WHO commission, 2007. Available: https://www.who.int/social_determinants/resources/ articles/emconet_who_report.pdf

8 Rodriguez-Loureiro L, Vives A, Martínez Franzoni J, et al. Health inequalities related to informal employment: gender and welfare state variations in the central American region. Crit Public Health 2020;30:306-18.

9 Ruiz ME, Vives A, Martínez-Solanas Èrica, et al. How does informal employment impact population health? Lessons from the Chilean employment conditions survey. Saf Sci 2017;100:57-65.

10 Benach J, Vives A, Amable M, et al. Precarious employment: understanding an emerging social determinant of health. Annu Rev Public Health 2014;35:229-53.

11 Vives A, Amable M, Ferrer M, et al. The employment precariousness scale (EPRES): psychometric properties of a new tool for epidemiological studies among waged and salaried workers. Occup Environ Med 2010;67:548-55.

12 International Labour Organization. Decent work and the sustainable development goals: a guidebook on SDG labour market indicators. Geneva: ILO, 2018. https://www.ilo.org/stat/Publications/WCMS_ 647109/lang--en/index.htm

13 United Nations. Transforming our world: the 2030 agenda for sustainable development, 2015. Available: http://www.un.org/en/ development/desa/population/migration/generalassembly/docs/ globalcompact/A_RES_70_1_E.pdf

14 Benavides FG, Serra C, Delclos GL. What can public health do for the welfare state? occupational health could be an answer. $J$ Epidemiol Community Health 2019;73:1141-4.

15 Bambra C, Lunau T, Van der Wel KA, et al. Work, health, and welfare: the association between working conditions, welfare states, and selfreported general health in Europe. Int J Health Serv 2014;44:113-36.

16 Martínez Franzoni J. Domesticar La incertidumbre en América Latina: Mecado laboral, politica social Y familias. Inst Investig Soc 2008;297 http://bibliotecavirtual.clacso.org.ar/Costa_Rica/iis-ucr/ 20120726031307/Domesticar.pdf

17 UN. World mortality 2017: data booklet. 2018:21, 2018. Available: www.unpopulation.org

18 CEDLAS, The World Bank. Socio-Economic database for Latin America and the Caribbean (SEDLAC), 2018. Available: http://www. cedlas.econo.unlp.edu.ar/wp/en/estadisticas/sedlac/metodologiasedlac/\#1496251194841-0db46f2f-cc48
19 International Labour Organization (ILO). Measuring informality: a statistical manual on the informal sector and informal employment. Turin - Italy, 2013. Available: https://www.ilo.org/wcmsp5/groups/ public/---dgreports/---dcomm/---publ/documents/publication/ wcms_222979.pdf

20 World Health Organization. WHO | mortality database, 2015 Available: https://www.who.int/topics/mortality/en/

21 Rothman KJ, Greenland S, Associate TLL. Modern epidemiology. 3rd ed. Philadelphia: Wolters Kluwer Health/Lippincott Williams \& Wilkins, 2008. http://www.ncbi.nlm.nih.gov/pubmed/24644503

22 Julià M, Belvis F, Vives A, et al. Informal employees in the European Union: working conditions, employment precariousness and health. $J$ Public Health 2019;41:e141-51.

23 ILO. Ratification of ILO conventions: Ratification by convention. NORMLEX Inf. Syst. Int. labour stand, 2015. Available: https://www. ilo.org/dyn/normlex/en/f?p=1000:11001:::NO

24 Economic Commission for Latin America and the Caribbean (ECLAC). Statistical Yearbook for Latin America and the Caribbean. Santiago: Naciones Unidas, 2019.

25 Vincens N, Emmelin M, Stafström M. Social capital, income inequality and the social gradient in self-rated health in Latin America: a fixed effects analysis. Soc Sci Med 2018;196:115-22.

26 Beckfield J, Krieger N. Epi + demos + cracy: linking political systems and priorities to the magnitude of health inequities-evidence, gaps, and a research agenda. Epidemiol Rev 2009;31:152-77.

27 Bambra C, Work BC. Work, worklessness and the politica economy of health inequalities. J Epidemiol Community Health 2011;65:746-50.

28 Montero-Moraga JM, Benavides FG, Lopez-Ruiz M. Association between informal employment and health status and the role of the working conditions in Spain. Int J Health Serv 2020;50:199-208.

29 Department of Information. Evidence and research WHO. WHO methods and data sources for life tables 1990-2016. Geneva, 2018. Available: http://www.who.int/gho/mortality_burden_disease/en/ index.html

30 World Health Organization, World Health Organization. Global health estimates 2016: deaths by cause, age, sex by country and by region 2000-2016, 2018. Available: https://www.who.int/healthinfo/global_ burden_disease/estimates/en/

31 WHO, Chan DM. Ten years in public health 2007-2017. Geneva: 2017, 2017. Available: http://apps.who.int/iris 